\title{
POLÍTICA E ESTRUTURAS DE PARENTESCO EM CAMPO LARGO (1871-2004), de Vanderlei Hermes Machado ${ }^{1}$
}

\author{
Fernando Marcelino Pereira ${ }^{2}$
}

\footnotetext{
- Enviado em 30/01/2016
}

- Aprovado em 24/03/2016

Em 2005, Vanderlei Hermes Machado concluiu o Mestrado em Sociologia pela UFPR com a dissertação intitulada "Política e Estrutura de Parentesco em Campo Largo (1871-2004)". Neste trabalho avaliado com conceito A (nota 10,0), sob orientação do Prof. Dr. Ricardo Costa de Oliveira, Vanderlei demonstra a relação histórico-social existente entre algumas famílias e o poder político do município.

O trabalho é dividido em seis capítulos. No primeiro, Vanderlei desenvolve o marco teórico da pesquisa. Primeiro expõe o conceito de "família histórica" como um grande complexo de unidades de parentesco de longa duração em determinada região. Seus membros, em cada geração, ocupam posições de destaque no cenário econômico, político e social, atravessando modos de produção, tipos de Estado e diferentes cenários políticos. Para análise das famílias históricas, Vanderlei se vale da genealogia para obter informações sobre a trajetória social de diversas gerações. Para dar confiabilidade a sua investigação, Vanderlei se baseia em documentos oficiais para verificar conexões familiares, identificar proprietários de latifúndios e os quadros dirigentes municipais, como Vereadores e Prefeitos, possuidores de títulos militares como de Coronel,

\footnotetext{
${ }^{1}$ Dissertação de autoria de Vanderlei Hermes Machado no Programa de Pós-Graduação em Sociologia da UFPR, em 2004, sob orientação do Prof. Dr. Ricardo Costa de Oliveira. A versão completa não está disponível na Biblioteca Digital da UFPR.

${ }^{2}$ Graduado em Relações Internacionais pelo Centro Universitário Curitiba (UNICURITIBA), Mestre em Ciência Política e Doutorando em Ciências Sociais na Universidade Federal do Paraná (UFPR). Membro do Núcleo de Estudos Paranaenses (NEP). Têm experiência na área de Sociologia e Ciência Política, com ênfase em pesquisas sobre classes sociais, estruturas de parentesco, poder político paranaense e tribunal de contas. Endereço eletrônico: fernandomarcelinopereira@gmail.com
} 
Tenente-Coronel, Major, Capitão e Alferes. Vanderlei também se valeu da história oral, com entrevistas gravadas sobre acontecimentos, conjunturas, instituições, modos de vida e outros aspectos da história passada e contemporânea com sujeitos envolvidos no poder político. Dessa forma, Vanderlei busca delinear a elite politicamente dominante de Campo Largo.

No segundo capítulo, expõem-se a origem histórica de Campo Largo, destacando-se os primeiros habitantes, suas trajetórias, o papel da Igreja e a questão fundiária local. Vanderlei lembra a trilha do Piabiru como elemento importante na constituição de Campo Largo. Este caminho partia da região de Cananéia, na costa sul de São Paulo, e prosseguia pelo Paraná. Por muito tempo este caminho foi a principal via por onde passavam bandeirantes, viajantes e aventureiros na corrida em busca do ouro e tropeiros na comercialização de animais vindos do sul do Brasil e de países como Argentina e Uruguai. Outra atividade crucial para o desenvolvimento local foi a erva-mate, principalmente a partir de 1870 quando a Estrada da Graciosa foi concluída, permitindo a ligação entre o litoral e o planalto paranaense.

No ano de 1871, Campo Largo foi elevada à categoria de município. A partir dessa data começa a formação dos primeiros quadros administrativos da localidade, com a Câmara Municipal como um lócus específico para exercer seu poder político. Seu aparato funcional passa a ser exercido quase sempre por grandes ervateiros, comerciantes varejistas e criadores de gado. Vanderlei mapeia 11 proprietários de engenho de erva-mate em 1880, formando uma burguesia que forneceu importantes quadros dirigentes ao município, destacando-se membros das famílias Ribeiro de Macedo, Kuster, Portella, Natel, Portugal, Vidal, Almeida Torres, Oliveira e Souza, Miller e Andrade.

A economia do mate criou as condições para a vinda de imigrantes europeus. Em Campo Largo, a imigração foi principalmente de italianos e poloneses, a princípio na agricultura e reunindo-se em pequenas comunidades ao redor de Igrejas construídas por eles mesmos. Vanderlei nota que muitas destas famílias mantinham estabelecimentos comerciais em tonos de Igrejas, dentre elas as famílias Soviersoski, Puppi, Castagnolli, Andreassa, Pianaro, Zanlorenzi e Bossani.

No terceiro capítulo, Vanderlei debate a relação entre estruturas de parentesco e poder político no município. É identificada a presença de pelo menos 23 famílias na história política do município, em postos no executivo e legislativo, totalizando um universo de 67 indivíduos analisados predominantemente pelas suas linhagens paternas de descendência. São famílias que ocupam posições de destaque no comércio, na indústria, em tabelionatos, em organizações partidárias e principalmente em cargos eletivos, como vereadores e prefeitos. Ele detalha cada uma 
delas em seu estudo. Conforme Vanderlei, existem famílias em Campo Largo que possuem até sete membros que já foram prefeitos, vereadores, ou ambos, possuindo vínculos políticos que muitas vezes remontam ao século XIX, descendentes de uma população formada basicamente por lusobrasileiros. Estas famílias compõem a classe dominante da região.

O quarto capítulo foca-se na constituição dos partidos políticos no município por serem o lócus principal da relação entre os grupos familiares identificados e o Estado. A partir de levantamentos no TRE-PR, Vanderlei analisa alguns dos principais membros dos partidos desde o Império. A dinâmica familiar da política em Campo Largo pode ser vista quando Conservadores e Liberais se alternavam como partido majoritário. Naquele período o Partido Conversador tinha como chefe local o influente Capitão Francisco Pinto de Azevedo Portugal, com apoio de Manoel Ribeiro de Macedo e das famílias Paula Xavier, Padilha e Natel, e o Partido Liberal era chefiado pelos coronéis Manoel Antonio de Andrade e por Domingos Cunha, tendo como correligionários membros das famílias Soares Pinto, Martins da Rocha, Lobo Moura e Torres. Famílias estas que mantiveram por mais de um século seu poder na cidade, considerando a integração de novas famílias como os Barbosa após a Revolução de 1930, a família Vidal, Puppi, Castagnoli e Soviersoski após 1945. Depois nos anos 1960 começa a ascender na disputa política as famílias Sávio e Bassani, Braga, Zanlorenzi, Pianaro e Gabardo. O quinto capítulo que trata das relações de parentesco nos cartórios e tabelionatos. É expressiva a participação de membros da família Portugal, Guimarães, Cercal, Padilha, Andrade e Poli Kurowski, o que demonstra forte concentração de poder dessas famílias pela manutenção destas instituições de geração em geração por mais de 130 anos.

Nas considerações finais é estabelecido um sistema de classificação das informações, dividindo as 23 famílias analisadas pelo local de nascimento, origem de suas descendências, atividades profissionais, participação em cargos eletivos e liderança partidária. Dos 67 indivíduos identificados, 37 deles têm Campo Largo como terra natal. A grande maioria são descendentes de portugueses, mas também encontram-se italianos e poloneses, com visível predominância de comerciantes e empresários.

A dissertação de Vanderlei merece algo mais do que um breve resumo de seus principais achados por ser um trabalho inovador, pleno de descobertas e sugestões para um entendimento mais exato sobre a política de Campo Largo. Ao estudar a genealogia das famílias com membros em posições chave no governo, na câmara, nos cartórios e partidos, Vanderlei mostra a concentração familiar do poder local. O trabalho de Vanderlei é também uma contribuição original ao estudo das 
formas de representação de interesse na região. Através dessa ferramenta de pesquisa, conseguiu traçar a trajetória das famílias da região no decorrer dos séculos e identificou os deslocamentos sofridos por elas no tempo e no espaço, seu desenvolvimento quantitativo e qualitativo, a influência de seus membros em uma sociedade, entre outros aspectos. 